TAPROBANICA, ISSN 1800-427X. December, 2013. Vol. 05, No. 02: pp. 156.

(C) Taprobanica Private Limited, 146, Kendalanda, Homagama, Sri Lanka.

http://www.sljol.info/index.php/tapro

\section{First sighting of Long-tailed duck from West Bengal}

Long-tailed duck, Clangula hyemalis is vulnerable and one of the rare vagrants in Indian subcontinent. This species was first sighted in Arunachal Pradesh in 1935 (Parsons, 1935), subsequently, in Kashmir (Ludlow, 1940), Uttarakhand (Mohan et al., 1992), and Punjab in 2001 (Prasad, 2008). On 21 February 2013, Shantanu Prasad sighted a single female long-tailed duck at Gajoldoba, West Bengal. This is the first record of this bird from Eastern India observed on 28 February 2013 (Fig. 1). Gajoldoba $\left(26^{\circ} 40^{\prime} \mathrm{N}, 88^{\circ} 29^{\prime} \mathrm{E}\right)$ is a barrage on the River Teesta situated, $25 \mathrm{~km}$ south-east of Siliguri town in Jalpaiguri District of West Bengal. Biogeoraphically, the site falls in the Lower Ganjetic Plain (7B) biotic province of India (Rodgers et al., 2002).

The female duck remained for a period of three weeks until the water level of the barrage reduced considerably. It preferred foraging in early morning $\sim 06: 30 \mathrm{~h}$ near to the shore with the flock of other diving ducks such as Aythya fuligula and Aythya ferina, etc. When the sun becomes brighter, the duck gradually shifted to deeper water of the barrage and rest of the time it was seen either busy in grooming activities or sleeping with its bill tucked into its back feathers. The reservoir and the surrounding area of Gajoldoba barrage is one of the important wintering abode of several other migratory bird species like, Aythya nyroca, Aythya marila, and Anas platyrhynchos. Therefore we recommend immediate protection and further investigation of this important wetland.

\section{Acknowledgements}

We are grateful to the Director (ZSI) for granting permissions. Special thanks to our Parents for their endless support for us. Finally Johanna Bleecker (McGill University, Canada) is acknowledged for language editing.

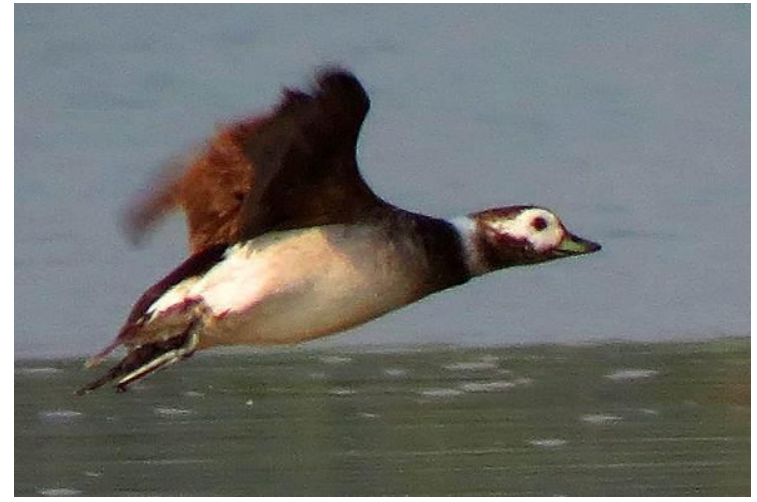

Fig. 1: The long-tailed duck (photo: D. Gupta).

\section{Literatures Cited}

Ludlow, F., 1940. The Long-tailed Duck (Clangula hyemalis) in Kashmir. Journal of Bombay Natural History Society, 41: 666.

Mohan, D., N. D. Rai, and A. P. Singh., 1992. Longtailed Duck or Old Squaw Clangula hyemalis (Linn.) in Dehra Dun, Uttar Pradesh. Journal of Bombay Natural History Society, 89: 247.

Parsons, R. E., 1935. A second record of the occurrence of the Longtailed Duck (Clangula hyemalis Linn.) in India. Journal of Bombay Natural History Society, 38: 193-194.

Prasad, A., 2008. Long-tailed Duck Clangula hyemalis at Harike Lake, Punjab, India. Indian Birds, 4: 16-17.

Rodgers, W. A., H. S. Panwar and V. B. Mathur, 2002. Wildlife Protected Area Network in India: A review (Executive Summary). Wildlife Institute of India, Dehra Dun, India.

Submitted: 25 July 2013, Accepted: 19 Nov. 2013 Sectional Editor: Varadharajan Gokula

$$
\text { A. } \text { Raha }^{1} \& \text { D. Gupta }{ }^{2}
$$

${ }^{1}$ Zoological Survey of India, Prani Vigyan Bhavan, M-Block, New Alipore, Kolkata 700053, West Bengal, India; E-mail:adroitangshuman@gmail.com 2 185/1A, N.S.C. Bose Road, Kolkata 700040, West Bengal, India; E-mail: debanta_gupta@yahoo.com 